\title{
Analysis of Counseling Services Implementation By Pharmacist at Private Pharmacies in Padang 2019
}

\author{
Sri Siswati ${ }^{1^{*}}$, Mira Cantika ${ }^{1}$, Ayulia Fardila Sari ZA ${ }^{1}$ \\ ${ }^{I}$ Public Health Faculty, Andalas University, Padang, Indonesia \\ *Corresponding author. E-mail: srisiswati@yahoo.co.id
}

\begin{abstract}
The implementation of counseling services by Pharmacists in Private Pharmacy in Padang has not run optimally. The purpose of the study was to analyze the implementation of counseling services by pharmacists in private pharmacies in the Padang in 2019. Type of qualitative research with a systems approach, as many as 12 research informants, purposive sampling informant determination techniques. Data collection method by in-depth interviews, observation, and document review. Data analysis was performed with content analysis. Data processing used triangulation of sources and methods. Based on the results of research, the implementation of counseling services in Private Pharmacy in Padang, has not referred to the Regulation of the Minister of Health Number 73 of 2016. The number of human resources is sufficient, funds sourced from the personal funds of the pharmacy owner, facilities and infrastructure are not yet sufficient, Standard Operational Procedure for pharmacy services at the pharmacy is not yet available. Policy socialization has been done through seminars and workshops, special training for counseling services has never been done, pharmacist practice services have not been paid according to the standards of professional organizations, coaching and supervision are still lacking. The implementation of counseling services in Private Pharmacy in Padang has not run optimally. The main obstacle is Pharmacists are not yet fully available in pharmacies, there is no counseling room, training is rarely done, and there is still a lack of guidance and supervision conducted by stakeholders. It is expected that an innovation based on information technology in accordance with the Industrial Revolution 4.0.
\end{abstract}

Keywords: counseling services, pharmacists, information technology

\section{INTRODUCTION}

Health is a human right and one of the elements of well-being that must be realized in accordance with the ideals of the Indonesian people. The Health Law states that pharmaceutical practices must be carried out by health workers who have expertise and authority. Pharmacists are health workers who have the authority to do pharmaceutical work.

The role of the pharmacist is required to increase knowledge, skills and behavior in order to carry out direct interactions with patients. The forms of interaction include the provision of drug information, counseling, and monitoring of drug use to patients. One way pharmacists can promote good health is by counseling patients

In line with the laws and regulations and the development of science and technology and the demands of patients and the community for improving the quality of pharmaceutical services, requires a change from the old paradigm oriented to the product into a new patient-oriented paradigm. This paradigm change is known as pharmaceutical care.
Pharmaceutical care or pharmacy service is a pattern of pharmacy service that is patient-oriented.

The number of private pharmacies in the city of Padang is 200 pharmacies. Based on the initial survey conducted in 35 private pharmacies in the city of Padang, it was found that the frequency of attendance of pharmacists and pharmacy services at pharmacies is still categorized as less because most of the pharmacists managing pharmacies who come once a week namely as many as 16 pharmacies (45.71\%), pharmacists managing pharmacies who come 2 times a week namely as many as 10 pharmacies (28.57\%), pharmacists managing pharmacies that come once a month that is as many as 6 pharmacies (17.14\%), pharmacists managing Pharmacy that comes every day is as many as 3 pharmacies (8.57\%). Most of the personnel doing pharmacy work at the Pharmacy are Assistant Pharmacists and Non Pharmacists, according to Government Regulation Number 51 Year 2009 confirms that pharmacy work at pharmacies is carried out by pharmacists. In article 22 paragraph 2 Health Ministry Policy No. 1332 of 2002 states that 


\section{Fund}

Funds to support the implementation of counseling services by pharmacists in private pharmacies in the city of Padang do not yet exist. There is no funding for the implementation of counseling services by pharmacists in private pharmacies in Kota Padang. If viewed in terms of the direction of the use of the budget in pharmaceutical services, the budget made by the owner of the pharmacy is more towards pharmaceutical preparations in pharmacies and for practical services. Financing or budget is an important instrument in the management of a program because it is part of the management function. Therefore, funds are a very important component for achieving goals because everything must be rationally calculated.

\section{Facilities}

Availability of facilities and infrastructure in the implementation of counseling services by pharmacists in private pharmacies is still inadequate as there is no counseling room / counseling table. The availability of facilities and infrastructure in private pharmacies in the city of Padang has not been sufficient to support the implementation of counseling services by pharmacists in private pharmacies in Padang City as there is no room / specific place for counseling.

\section{Inputs \\ Policy}

There is already a policy from the Ministry of Health and professional organizations in realizing the implementation of counseling services by pharmacists in Padang's private pharmacy. Policies in the form of Peraturan Daerah/ Peraturan Walikota or Leader Regulation do not yet exist are still being planned by the City Health Office. The city of Padang uses the Regulation of the Minister of Health of the Republic of Indonesia Number 73 Year 2016 concerning Pharmaceutical Service Standards in Pharmacy which is used as a guideline for pharmaceutical personnel in carrying out pharmacy services in pharmacies. This policy has been disseminated to pharmacy workers in the form of seminars and workshops by the City / Provincial Health Office together with professional organizations. Policies in pharmaceutical services are sufficient to support the implementation of counseling services by pharmacists in private pharmacies. However, its implementation in the field has not yet proceeded because of the still weak supervision and guidance from the City / Provincial Health Office and professional organizations.

\section{Human Resources}

The number of pharmacy workers in a private pharmacy in Padang City is 1 (one) pharmacist in charge and for pharmaceutical technical staff there are 1 to 3 people, depending on the size of the pharmacy. That personnel in the implementation of counseling services in private pharmacies in the city of Padang are sufficient. Personnel involved in the implementation of counseling services in private pharmacies in the city of Padang are pharmacists who can be assisted by pharmaceutical technical personnel.

\section{Standard Operating Procedures}

Pharmacists in private pharmacies in the city of Padang do not have Standard Operating Procedures (SOPs) in conducting counseling services at pharmacies. Private pharmacies in the city of Padang do not yet have standard operating procedures (SOP) in conducting counseling services at private pharmacies in the city of Padang. Guidelines, or technical guidelines, or SOPs affect the performance of officers. This is consistent with Yayan's (2017) study which states that the work environment and standard operating procedures have a positive effect on productivity, the work environment and standard operating procedures simultaneously affect employee productivity.

\section{Process}

\section{Socialization}

The socialization on pharmaceutical regulations has been carried out by the Provincial / City Health Office, BPOM, and professional organizations in the form of seminars and workshops. Socialization is a very important aspect in the entire policy process. Policies that have been made will be useful if socialized. Based on the results of the study note that the Minister of Health Republic Indonesia Number 73 on 2016 year about pharmacy service standards at the pharmacy has been socialized but the pharmaceutical staff do not know about this regulation.

\section{Training}

Training on the implementation of counseling services by pharmacists in private pharmacies in the city of Padang has never been done by the City / Provincial Health Office and professional organizations. One of the activities carried out by the Regional Management of the West Sumatra Indonesian Pharmacist Association is the Pharmacist 
conducting counseling services at pharmacies, pharmaceutical staff do not yet have Standard Operating Procedures (SOP).

\section{Element of Process}

Socialization of pharmaceutical regulations has been carried out by the Provision / City Health Office, BPOM, and professional organizations in the form of seminars and workshops. Training on the implementation of counseling services by pharmacists in private pharmacies in Padang City has never been done. Pharmacist practice services are not paid according to the standards of the professional organization or notarial deed of agreement between the owner of the pharmacy facility and the pharmacist. Development and supervision of the implementation of counseling services has never been done by the City / Provincial Health Office and professional organizations.

\section{Element of Outputs}

The implementation of counseling services in private pharmacies in Padang City is still not running optimally. Implementation of counseling services by pharmacists in private pharmacies in the city of Padang has not been carried out in accordance with Peraturan Menteri Kesehatan (Ministry of Health Regulation) Republic Indonesia Number 73 of 2016 concerning pharmacy service standards at pharmacies. The main obstacles that become obstacles are the absence of pharmacists at the pharmacy, there is no counseling room / place, there is no training on counseling services, pharmacist practice services that are not in accordance with professional organization standards, and the weak guidance and supervision carried out by the City / Provincial Health Office and professional organizations in the implementation of counseling services by pharmacists in private pharmacies in the city of Padang.

\section{REFERENCES}

[1] Republic of Indonesia Law 36/2009 concerning Health. 2009

[2] Hartini YS. The Relevance of Regulations in Supporting

[3] Pharmacist Professional Practices in Pharmacy. Pharmacy Science Magazine. 2009; Vol.VI, No. 2, 97 - 106.

[4] Indonesian Pharmacist Competency Standards. Jakarta 2011.

[5] Kwando RR. Mapping the Role of Pharmacists in Pharmaceutical Services Related to the Frequency of Presence of Pharmacists at Pharmacy in East Surabaya. Calyptra Scientific journal of Surabaya university students. 2014; Vol.3.No.1

[6] Baroroh F, Darmawa E. Evaluation of the Implementation of Drug Counseling location and low pharmacy income are the main factors of the lack of facilities and infrastructure in the pharmacy. In 
Services in Yogyakarta City Pharmacy. Clinical and Community Pharmacy Faculty of Pharmacy Ahmad Dahlan University Yogyakarta. Pharmacists. 2016; Vol. 3. No. 1

[7] Baroroh F. Code No. DAR2 / Professional /582/004/2018 Deepening of Pharmaceutical Material, Module 004: Pharmaceutical Regulations of the Ministry of Education and Culture Ministry of Research, Technology and Higher Education 2108.

[8] Rantucci MJ. Pharmacist-Patient Communication Patient Counseling Guide, Edition 2, translated by Sani, A. Jakarta: EGC Medical Book; 2009

[9] Regulation of the Minister of Health of the Republic of Indonesia Number 73 Year 2016 Concerning Pharmaceutical Service Standards in Pharmacy. Jakarta: Ministry of Health Republic of Indonesia 2016.

[10] Regulation of the Minister of Health of the Republic of Indonesia Number 74 Year 2016 Concerning Pharmaceutical Service Standards in Puskesmas. Jakarta: The Indonesian Ministry of Health; 2016

[11] Monita. Evaluation of the Implementation of Pharmaceutical Services at the Pharmacy in the City of Padang. In Abstract and Summary of Research Results in 2009. Yogyakarta, DIY, Indonesia: Electronic thesses \& dissertations (ETD) Gadja Mada University; 2009

[12] Regulation of the Minister of Health of the Republic of Indonesia Number 9 Year 2017 Regarding Pharmacy. Jakarta: The Indonesian Ministry of Health; 2017.

[13] Christina DAK. Drug Therapy Problems in patients who receive polypharmacy prescriptions (study at Pharmacy Pharmacy Airlangga Surabaya). Journal of Community Pharmacy. 2014; Vol.1, (2014) 17-22.

[14] Widya Kardela RA, Sudibyo Supardi. Comparison of Rational Drug Use Based on WHO Indicators in District

[15] Health Centers between Depok City and South Jakarta 2014.

[16] Padang City Health Service. Profile of Padang City Health Office 2017. 2017.

[17] Decree of the Minister of Health of the Republic of Indonesia Number: 1332 / Menkes / Sk / X / 2002 concerning Provisions and Procedures for Granting Pharmacy Licenses. 2002 